\title{
Insurance with Rent Schemes: An Empirical Study of Market Provision and Consumer Demand
}

\author{
John Hood, William Stein and Claire McCann \\ Glasgow Caledonian University, The Britannia Building, City Campus, Cowcaddens Road, Glasgow G4 \\ 0BA, U.K. E-mail: w.stein@gcal.ac.uk
}

In the U.K., home contents insurance is widely available, with a reduction in the number of "traditional" insurance companies offering cover being offset by a growth in the availability through "non-traditional" providers such as supermarkets, motoring organizations and even energy providers. Research suggests that while around 80 per cent of all households are covered by home contents insurance, only around 50 per cent of people living in rented or local authority housing insure their contents. The low uptake is undesirable for two reasons. Firstly, financial exclusion is a phenomenon whereby individuals or sectors of society are deliberately, or effectively, denied access to financial services products, including home insurance, and it is commonly government policy to reduce such exclusion. Secondly, possession of contents insurance by householders minimizes the possibility that after a catastrophic loss such as flooding, uninsured persons will seek emergency assistance and temporary housing at the expense of their local authority. Studies and government reports exist that shed light upon the reasons behind the low purchase of conventionally marketed insurance. Special schemes exist to encourage purchase of insurance by enabling home contents insurance for local authority tenants to be paid for along with rent. Governments support such schemes. There appears to be little published research to indicate the extent to which such schemes are used by tenants. We survey local authorities in Scotland to determine the availability of "insurance with rent" schemes and their take-up rate by tenants. We find that many schemes exist, providing average market cover at typically average or lower cost and that there is no evidence of highly selective underwriting and pricing. Despite this easy availability of competitively priced, good policy cover, we find that the take-up rates by tenants are low. We consider reasons why apparently effective insurance products are not more popular. We conclude that local authorities and government need to promote the schemes with greater vigour. The Geneva Papers (2005) 30, 223-243. doi:10.1057/palgrave.gpp.2510030

Keywords: household insurance; home contents; financial exclusion; insurance with rent; local authority

\section{Home contents insurance for tenants in public sector housing}

This paper is based on empirical research analysing the availability of what have become known as "insurance with rent" schemes in Scottish public sector housing and the take-up rates by tenants. It is axiomatic that, in general terms, there is a market for home contents insurance. Although, by reason of insurer mergers and the decline of industrial (or home service) insurance, the number of "traditional" insurance companies providing this form of cover may have decreased in recent years, there has been a significant growth in the availability of cover through non-traditional 
providers such as supermarkets, motoring organisations and even energy providers. At a superficial level, it appears that insurers have been successful in creating a market to meet the demand for household insurance. The proportion of households that are uninsured has, however, remained fairly constant over the past 20 years. ${ }^{1}$ Highly detailed research carried out by Whyley et al. ${ }^{2}$ found that, in the U.K., 80 per cent of households are covered by home contents insurance. The distribution of the uninsured 20 per cent is not, however, evenly spread across the socio-economic spectrum. An inquiry carried out by the Office of Fair Trading $(\mathrm{OFT})^{3}$ discovered that, generally, those without home contents insurance are:

Lone parent families, young families, households with low income, head of the household unemployed and those with little or no savings. Additionally, tenants and households living in inner cities and economically and socially deprived areas were also found to have low take up rates.

This OFT report found that 93 per cent of homeowners insured their contents but that only 51 per cent of people living in rented or local authority housing insured their contents. Research established that around 50 per cent of those who did not have insurance cover had at one time held a policy but had let it lapse - largely due to financial pressures. The absence of home contents insurance for tenants is undesirable on (a) philosophical grounds relating to social justice and financial exclusion, and (b) on practical grounds relating to the costs of emergency relief provided to uninsured tenants.

\section{The philosophical case for promoting purchase of home contents by public sector tenants}

Financial exclusion is frequently included under the general heading of social exclusion and tackling it has been identified as a method of promoting wider social inclusion. ${ }^{4}$ The debate surrounding social exclusion is not, however, a U.K.-specific one. Indeed, the Financial Services Authority ${ }^{5}$ identify that it has long been a feature of policy debates in Europe and beyond. ${ }^{6}$ For the purposes of our research, we have confined our analysis of insurance provision for low-income houses to the U.K. However, given the importance of financial exclusion globally, a more international analysis would be a relevant area for future study. Initial evidence would suggest that, in the context of insurance, attempts to tackle this global aspect of financial exclusion

\footnotetext{
${ }^{1}$ Lewis (1989); National Consumer Council (1994); ABI (1995).

${ }^{2}$ Whyley et al. (1998a).

${ }^{3}$ OFT (1999, p. 27).

${ }^{4}$ British Bankers Association (2000).

${ }^{5}$ Financial Services Authority (2000).

${ }^{6}$ See, for example, Combes (1998) and Bronheim et al. (2000).
} 
has often focused around the use of "micro-insurance". This has been defined by the Canadian Cooperative Association ${ }^{7}$ as:

... a modern response to those needs: voluntary and contributory schemes among groups of poor communities to pool risk and enable low-income members to meet unpredictable burdens of out-of-pocket expenses.

These micro-insurance schemes include many forms of cover, for example, property, life and health insurance for individuals as well as commercial insurance for small businesses. They do, however, appear to be a feature of developing and transitional economies $^{8}$ rather than a mechanism for dealing with financial exclusion in developed economies. Although, therefore, the insurance with rent schemes that we discuss share some superficial similarities to micro-insurance schemes, there are major differences that would render any direct comparisons invalid.

Important though the analysis of social exclusion in its widest sense is, ${ }^{9}$ our paper will focus on the issue of financial exclusion and analyse specifically the question of exclusion from one particular type of financial services product - home contents insurance. Financial exclusion is a phenomenon whereby individuals or sectors of society are deliberately, or effectively, denied access to financial services products including home insurance and it is government policy to reduce such exclusion. Sinclair ${ }^{10}$ found that 50 per cent of financially excluded live in the most deprived local authority districts in Britain and that 80 per cent of financially excluded households live in local authority or housing association accommodation. The term financial exclusion is one which has passed into common currency, often without a clear understanding of what it actually means. A comprehensive and relevant definition of financial exclusion is:

Financial exclusion refers to the inability of individuals, households or groups to access necessary financial services in an appropriate form. Exclusion can come about as a result of problems with access, conditions, prices, marketing or selfexclusion in response to negative experiences or perceptions. ${ }^{11}$

Additionally, as identified by the U.K. Financial Services Authority, financial exclusion is:

A shorthand term for what can happen when people or areas suffer from a combination of linked problems such as unemployment, poor skills, low incomes, poor housing, high crime environments, bad health, poverty and family breakdown. ${ }^{12}$

\footnotetext{
${ }^{7}$ Canadian Co-operative Association (2002).

${ }^{8}$ See USAID $(1999,2000)$ and DFID (2004).

${ }^{9}$ See Office of the Deputy Prime Minister (2004).

${ }^{10}$ Sinclair (2001).

${ }^{11}$ CRSIS (2003, p. 2).

${ }^{12}$ U.K. Financial Services Authority (2000, p. 7).
} 
Palmer et $a l .{ }^{13}$ identified a number of indicators that signify financial exclusion and concluded that one form of financial exclusion is being without household insurance.

At a superficial level, financial exclusion could be interpreted as a phenomenon whereby individuals or sectors of society are deliberately denied access to a range of financial services products, that is, the financial services industry chooses to exclude them. In many ways, this would square with the "red-lining" accusation ${ }^{14}$ which has periodically been levelled against insurers. ${ }^{15}$ Proponents of this argument would claim that insurers have a deliberate and conscious policy of refusing to offer insurance (most typically general insurance rather than life insurance) to whole sections of a community by reason of where they happen to live. As insurers' systems of rating have become more sophisticated, the potential to identify areas that may be unattractive to them has increased. Regardless of this potential for discrimination, the case against insurers remains unproven. For example, Gill and Turbin ${ }^{16}$ identify, albeit based on research in a fairly small geographical area, that while insurers retain the right of risk selection, there appears to be no widespread policy of wholesale red-lining.

Since 1997, New Labour has focused heavily on the issue of financial exclusion. The aim of the Social Exclusion Unit (SEU) created by New Labour in 1997 is to tackle social exclusion and in addition combat financial exclusion. Given that central government has placed considerable importance on tackling financial exclusion, it is unsurprising that it is on record as seeking to encourage the development of insurance with rent schemes.

An increasingly important element of financial exclusion is that of the growth in ITbased marketing and purchasing of financial products including insurance. As insurers seek to maximize the use of new technology, with the inevitable corollary being a reduction in the more traditional local branch structure, there is a danger of large sections of society being excluded from the on-line provider/customer loop. Despite government initiatives in a number of countries, there is strong evidence that sections of society are either completely excluded from the digital age, or their access to it is extremely limited. Research ${ }^{17}$ has identified wide discrepancies in internet access across socioeconomic groupings, with, perhaps unsurprisingly, those in the lower groups having much less IT involvement. This socio-economic barrier is exacerbated by exclusion based on prior levels of educational achievement. ${ }^{18}$

While it would be naive to assume that financial exclusion is a new phenomenon, it could be argued that, at least in the U.K., a number of factors have coalesced in the past $10-15$ years, which are likely to have exacerbated the situation as regards personal lines insurance. In addition to the use of IT for the purchase of insurance, these factors include the overall reduction in the number of providers through mergers and acquisitions, the rationalizing of insurers' operations, that is, branch closures, and the substantial reduction in the number of companies offering door-to-door collection of

\footnotetext{
13 Palmer et al. (2003).

${ }^{14}$ Gill and Turbin (1997).

15 Association of London Authorities (1994).

${ }^{16}$ Gill and Turbin, op. cit.

${ }^{17}$ For example Carvin (2000); Mansell (2002); Davison and Cotten (2003).

${ }^{18}$ See Allen and Rainie (2002); Hargittai (2002).
} 
premiums, the old-style Industrial Branch business. The latter in particular was a mainstay in areas where there was a high concentration of relatively low-income families staying in public sector, rented housing. This will have been offset to some extent by the growth in the availability of cover through non-traditional providers such as supermarkets, motoring organizations and even energy providers but those, typically, involve payments by bank direct debits or by credit cards. On an a priori basis, therefore, it would be reasonable to hypothesize that many such consumers are in danger of being excluded from the personal lines market.

\section{The practical case for promoting purchase of home contents by public sector tenants}

There is an economic case for local authorities to promote the purchase of home insurance by their tenants. In the case of major fire, explosion or flooding, persons without any cover are likely to turn to the local authority (and others, such as charitable organisations) for accommodation, support and emergency payments. Even if money does not change hands, there may be household basics to be supplied and temporary shelter accommodation (i.e. some matters that a home contents insurance policy would pick up) and there will be time tied up with provision of advice by social workers and the like. Possession of contents insurance by tenants will minimize the possibility that after a catastrophic loss such as fire or flood, uninsured persons will seek emergency assistance and temporary housing at the expense of their local authority.

There is a central government dimension to the economic case. In addition to fulfilling its social policy agenda, it also has to be recognized that government has an economic agenda, in that large-scale uninsurance, especially at times of widespread incidents such as flooding, is likely to result in calls for the public sector to assist the victims. By actively promoting insurance schemes as part of financial inclusion, the government is, arguably, seeking both to pursue a social imperative and to facilitate transfer of risk to the insurance industry.

\section{What are the reasons for low levels of home contents purchase by public sector tenants?}

In 1991 the U.K. government reported that those financially excluded tended to be so because of a mismatch between potential customers' needs and the products on offer. ${ }^{19}$ Furthermore, households in deprived communities tended not to purchase home contents insurance because of "cost, restrictive policy conditions, inconvenient payment methods and lack of information". ${ }^{20}$ Higher excesses and minimum sums insured imply that high street policies offered by leading insurers may not appeal to tenants on the basis of affordability. In addition, the emergence of telephone purchase, a growth in the use of insurance internet sites, and payment by direct debit, ensures

\footnotetext{
${ }^{19}$ HM Treasury $(1999$, p. 1).

${ }^{20}$ Ibid., (p. 2).
} 
inaccessibility of such policies for those without access to these products. Paradoxically, many of those who do not have easy access to household contents insurance are those who may be most likely to need it. For example, Palmer et al. ${ }^{21}$ found that households with no insurance cover are much more likely to be burgled than those who do have it. Property crime is severe for those on low income without household insurance for the simple reason, according to Palmer et al. ${ }^{22}$ that they are less likely to replace stolen goods themselves. Such findings indicate the need for alternative insurance markets that reach all sectors of society.

The Consumer Survey carried out by the Office of Fair Trading, ${ }^{23}$ highlighted various reasons for high rates of non-participation in insurance schemes:

- Insurance is said to be sold rather than bought. Insurers tend not to target lower ends of the scale as much as they do with home owners. This can be substantiated as the OFT found that 65 per cent of respondents surveyed who had a university degree had been approached to buy home contents insurance in comparison to 29 per cent of those with no qualifications at all.

- There is a distinct correlation between low-income families and living in high-risk areas. The higher the risk of crime in an area the higher the premium; those in highrisk areas tend to be of low income and are financially excluded households and may not be able to afford insurance or may think that it is less of a priority in comparison to other factors like food and clothing.

- High street insurance policies are not targeted at low-income families. High street policies have high minimum sums insured and high excesses among other things.

- Lack of access to a direct debit facility may be a contributing factor to nonparticipation in insurance schemes. Many families on a low income tend to be tenants and do not have bank accounts. According to the Social Exclusion Unit, "about one and a half million low-income households use no financial services", meaning that people would therefore have to rely on cash payments as they do not have the option to have the money uplifted from a bank account on a regular basis.

This evidence strongly points to the fact that conventionally marketed and priced insurance policies are not aimed at low-income families. Those who wish to insure at a low financial level are, effectively though not by design on the part of the insurers, discriminated against as most insurance companies have relatively high minimum sums insured and minimum premiums. For the insurance industry, new policy acquisition costs are high. These costs include advertising, commissions to intermediaries, the time and skill of underwriting officials in considering applications and of processing new policy documents. These must be covered by premiums regardless of the amount that may be allocated to cover what is referred to as the "pure risk". This necessitates a practical, minimum level of premium. If any of those elements of cost can be cut out, as would be the case for any scheme providing a flow of business, the minimum premium may be reduced. There are different considerations

\footnotetext{
${ }^{21}$ Palmer et al. (2003).

${ }^{22} \mathrm{Ibid}$.

${ }^{23}$ OFT (1999, pp. 27-28).
} 
behind the use of minimum sums insured. Home contents policies are theoretically "full value" policies and are not subject to any condition of "average" (a scaling down of claim payment in relation to the degree of underinsurance) that might be found in some commercial property policies. Underinsurance is, however, a common problem for home insurers. To combat this, proposers are often provided with guidelines for the calculation of a correct sum insured but a more cost-effective and blanket approach for insurers is to impose a minimum sum insured, set at a level which in their experience they judge to be appropriate for the bulk of policyholders. This rules out time-consuming and costly discussions about the accuracy of lower sums insured at the proposal stage. It has the added advantage of cutting out much debate over adequacy of sum insured at the time of a claim.

According to the Scottish Household Survey 2003, 41 per cent of households have home internet access. Further, 87 per cent of households with a net income of over $£ 40,000$ have home internet access in comparison to those households with a net income of over $£ 6,000$ when the figure falls to only 16 per cent having access. ${ }^{24}$ Insurance companies use the internet as a tool for householders to personally arrange insurance and it is a growing substitute for more traditional methods involving personal contact with a broker or insurer branch office. The Scottish Executive survey identified that among adults in Scotland who use the internet, the most common purposes are: to use email (85 per cent); general browsing or surfing (72 per cent); and finding information about goods and services (67 per cent). ${ }^{25}$ Lower income households may be excluded from this distribution route due to reduced home internet access.

Affordability is also an issue. According to the 2002/2003 Family Spending Expenditure and Food Survey, household spending on a weekly basis averaged $£ 406$ in the U.K. with the lowest income groups spending $£ 136$ and the highest 10 per cent spending $£ 883 .{ }^{26}$ For households in the lowest income range, the highest categories of spending were food, non-alcoholic drinks, housing and fuel power. This contrasted with more affluent households where there are distinct differences in priorities when it comes to spending. For households in a higher income range the highest categories of spending were transport and recreation and culture. ${ }^{27}$ It would appear that lower income households have lower proportions of their total spending power available for discretionary spending on non-essentials. For this reason, home contents insurance may not be a spending priority. Insurance with rent schemes can address such issues if they are able to provide low-cost insurance policies that are more suited to tenants in low-income households on the basis of affordability.

\section{Promotion of insurance with rent schemes}

The provision of home contents insurance schemes for public sector housing tenants is a well-established development in the U.K., having existed on a small scale since 1980

\footnotetext{
${ }^{24}$ Scottish Executive (2003b, p. 91).

25 Ibid.

${ }^{26}$ National Statistics (2003, p. 11).

${ }^{27}$ Ibid., p. 12.
} 
but becoming more widespread during the 1990s. This increase in their development has been encouraged by both national and local government in the U.K., mainly as part of a wider agenda of combating "financial exclusion". These schemes are directed at low-income households in rented accommodation provided by public or quasipublic organizations and offer the tenant an affordable and reputable basic cover, which is paid for in a convenient way, usually in tandem with rent payments - hence the expression "insurance with rent". As an example, the key elements of one scheme are noted below. For reasons of confidentiality, neither the local authority (often referred to in the U.K. as the "Council") nor the Insurers are named.

- The Scheme offers a "standard" policy cover (i.e. there are no choices or options available).

- The premium rate is the same in whichever district of the Council a tenant resides i.e. a single rate. (A previous scheme insurer wanted to charge more for one specific geographical area that had, historically, been subject to a flooding incident. The Council resisted that and changed to a new scheme insurer in order to maintain a single rate).

- The Council issues the proposal/leaflet form. It is branded for the Council and given a title that clearly spells out its key characteristic - "Pay as You Go". A paper proposal form is used. This is obtainable from any Council offices or "online".

- Applications are submitted to the Council where an Insurance Section vets them and, if approved, creates the policy record "online". The U.K. Post Office Giro system is used for payments because this is the same as that used for the collection of rent. The Giro system is used because of wider access by tenants to Post Offices than to banks.

- The Council in this anonymized example has declined only one application - the reason was that the tenant had several criminal convictions.

- The Council sends the policy out to the tenant.

- There is no formal renewal - the policy carries on in force until a tenancy ends or the Council is asked to cancel it.

- If there are any mid-term alterations they are delegated to the Council rather than the scheme insurer.

- The scheme insurers offer a "helpline" - but that is primarily intended to assist with the progress of claims. Tenants with general administrative queries are required to either telephone or make a personal visit to a Council office.

- The Council takes a 15 per cent commission from the premiums. This is used to pay the salary costs of the clerk administering the scheme.

- The previous scheme insurer arranged a direct link to an approved loss adjuster based locally. The routine contact for the current scheme insurer is based far from the Council area and, effectively, the Council has little control over the administration of claims. This has not proven to be a problem. Claim forms are submitted by tenants to the Council. These are then validated (by stamping to confirm that cover is in force and that the premium has been paid). The tenant then mails the claim form to the scheme insurer. The helpline is used for immediate advice.

- The Council has a ready appreciation of the viability of the scheme because it knows what the premiums are (it collects them) and, periodically, the scheme insurer supplies a list of claims. 
In 2003, the Scottish Executive announced a funding package of $£ 400,000$ "to aid promotion of existing schemes because, in Scotland, 42 per cent of tenants have no contents insurance". ${ }^{28}$ Palmer et al. ${ }^{29}$ found that nearly all of the 32 Scottish local authorities have at least one geographic area with a high proportion of people on low income. The Scottish Executive aim to ensure that tenants who might in other circumstances never bother to insure their household possessions (and the extras such as personal liability that go with such a policy) are given encouragement to do so as a result of the affordability and accessibility of policies that are offered. Nationally, the U.K. government aims, by the end of 2005, to increase the level of low-income households using banking and insurance to levels similar to other social groups. ${ }^{30}$

Since there is an accepted imperative for financial inclusion, it may be reasonable to question the U.K. strategy vis-à-vis home contents insurance. A number of studies ${ }^{31}$ have all recognized the role that local authorities, housing associations and credit unions can play in bridging the gap by promoting low-cost insurance policies that are more suited to those presently uninsured. For example, a recent experience of flooding in Glasgow has led to the Scottish Executive promising to explore ways of promoting the inclusion of insurance in rent payments. ${ }^{32}$ A number of social housing organizations already provide access to such policies and, according to the OFT, ${ }^{33}$ often do so in conjunction with measures to improve physical security and thus reduce levels of risk. In a report analysing schemes to improve quality of life, the Scottish Executive explicitly states:

We will investigate the feasibility of community based insurance schemes, through credit unions, initially for areas at risk of flooding. We will support home insurance schemes tied to rents paid to landlords in the socially rented sector. $^{34}$

Given that there is a strong government desire to use the public sector as a conduit through which low-cost insurance schemes provided by the market can be encouraged, we will now analyse a number of the extant schemes aimed at public sector housing tenants and discuss the extent to which consumers appear to have been attracted to these. Owing to recent developments in central government attitude towards local authority housing in the U.K., some local authorities have seen the transfer of housing stock from their direct control to various Housing Associations. As far as the tenants are concerned, however, their tenancy agreement remains very similar and the housing is still de facto public sector. Our definition of public sector housing will include residences owned and let by both of these categories of landlord.

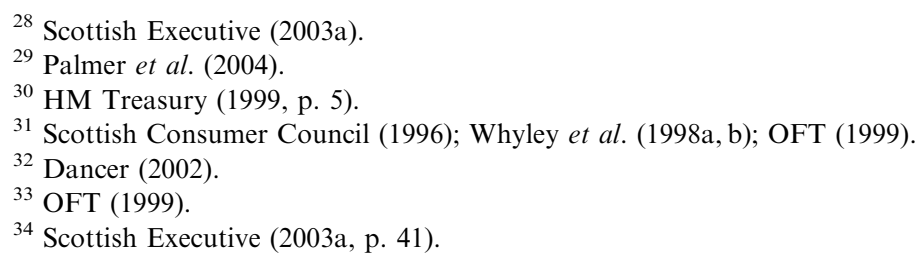


Local authorities, housing associations and credit unions have a prominent role to play by providing low-cost insurance policies. Housing associations currently operate schemes for tenants, which are comparable to those provided by local authorities. Throughout Scotland, the use of credit unions is considerable and the "Credit Union Members Financial Service" provides home contents insurances for members. ${ }^{35}$ These schemes appear to be similar to an average "high street" policy. Unlike most local authorities questioned in our study, it appears that policies offered via credit unions are formulated specifically for the household applying; for example, it takes into account the postcode rating, the risk of flooding/subsidence and the risk of theft. Nevertheless, the Scottish Executive states a commitment to explore the possibility of community-based insurance schemes through credit unions - particularly for areas at risk of flooding. ${ }^{36}$ The insurer Royal \& SunAlliance has launched an insurance scheme through the Post Office, using leaflets and TV adverts to advertise the scheme. The policy is aimed at people in lower income bands, those without bank accounts, and those past retirement age. Accessibility is enhanced because payment is made over the counter at the Post Office.

It has to be said that all such scheme arrangements are hardly charitable acts on the part of the insurers. Rather, they offer the possibility of providing insurers with a block of business which has low acquisition costs and a modest lapse rate. The downside for insurers is that they may have to take the "rough with the smooth" and, at least initially, accept as policyholders customers whose profile, as indicated by occupation or, possibly, by lack of occupation, or by postal address, they might otherwise decline. This is a sensitive subject of course for insurers who are anxious to deny any possibility that any "red-lining" tendencies ever exist. We stress that the purpose of this paper is not to focus on "red-lining", but to demonstrate whether or not there is a competitive insurance market that provides normal market cover at low cost, and the extent to which tenants avail themselves of such an opportunity.

A relatively recent, relevant and interesting development has been the insolvency of the Independent Insurance Company, which had significant involvement in local authority schemes. This emphasizes the role that authorities need to play in selecting a reputable insurer.

\section{Little published research to indicate the extent to which insurance with rent schemes are used by local authority tenants}

There is some published research and comment on the subject of access to home contents insurance for low-income households. ${ }^{37}$ Research has shown that those without home contents insurance tend to be located towards the lower end of the socio-economic spectrum. Statistically take up rates are lower among low-income families living in rented accommodation or local authority housing. ${ }^{38}$ A large

\footnotetext{
${ }^{35}$ HM Treasury (1999, p. 13).

${ }^{36}$ Scottish Executive (2003a).

${ }^{37}$ Gill and Turbin (1997); Whyley et al. (1998a, b); Kempson and Whyley (1999); Shires (2002).

${ }^{38}$ OFT (1999, p. 27)
} 
percentage of those without insurance cover previously let their policy lapse because of financial pressures. There appears, however, to be no published research to indicate the extent to which the public sector rented housing market have been able to successfully negotiate "insurance with rent" schemes and to promote them to their tenants.

\section{Research questions}

As discussed earlier in this paper, governments in many countries appear to have accepted, with very little demur, the need to foster social and financial inclusion. Ease of purchase of insurance is one aspect of financial inclusion. Low-income groups in general have been shown to be isolated from the conventional insurance market. By extension, it may be reasonable to hypothesize that local authority tenants (a typically low-income group) will also demonstrate low levels of purchase of home contents insurance. We do know that insurance with rent schemes have been developed as a way to offer tenants an affordable and reputable basic cover paid for in a convenient way. We do not know how widespread such "insurance with rent" schemes are or the take-up rates by tenants. It will be a useful addition to the knowledge in this area to examine the experience in local authorities in Scotland. We, therefore, undertook empirical research designed to answer the following questions:

(1) Do local authorities in Scotland (or any Housing Associations to which they have transferred housing stock) operate an "insurance with rent" scheme for tenants' home contents?

(2) Where schemes exist, what is the take-up rate by tenants?

(3) Where schemes exist, are they more or less favourable than policies available generally to the insuring public, in terms of the nature of the cover provided, acceptance criteria, price and conditions or exclusions?

\section{Methodology}

To answer our research questions as set out above, we surveyed all 32 local authorities in Scotland. We made direct contact by telephone with each of the Scottish authorities. This revealed early on that one local authority, Highland Council, had simultaneously launched their own postal survey (on insurance with rent schemes) of all Scottish authorities and that, if made available to us, would go some way to answering our research questions. ${ }^{39}$ The Highland Council survey (with return requested by 16 January 2004) took the form of a single page containing the following questions:

1. Do you have a Tenants' Home Contents Insurance scheme?

2. If so, what is the name of the insurer?

3. How many tenancies does the Council have?

4. What is the percentage take up rate for the scheme?

\footnotetext{
${ }^{39}$ Highland Council (2004).
} 
5. Does the Council finance the operation of the scheme?

6. Is the scheme self-financing?

7. Is there a single premium rate?

8. If there is more than one premium rate, are they banded by Post Code?

9. Are there any special exclusions?

10. Have you experienced any difficulties in setting up the scheme?

11. Any other comments on your experience of the scheme that consider might be helpful to other Councils?

Highland Council received 30 responses (out of a possible 32) of which 24 had insurance with rent schemes in operation. The two non-responders were very different in character, one being a high population density city council and the other being a low population density island council. The number of tenanted homes in Scottish local authorities is shown in Table 1. A column has been included to note area and population density - to provide the reader with some sense of the variation in character of each local authority and to emphasize that authorities range from concentrated urban to sprawling rural.

The Council generously agreed to share the results of this survey with us. It is recognized that this survey was devised for a purpose quite different from the academic research which was driving our study, but we consider this to be a minor limitation. The main topic areas of their survey were broadly similar to our own objectives and the close relationship between many Scottish local authorities resulted in a strong response rate. The authors of this paper then continued with a telephone approach to local authorities in order to obtain the information that we required but which had not been provided by the Highland Council survey. We chose to match exactly the response experience of the Highland Council survey and did not pursue any information from the two non-responders to that survey. Our enquiries included, for example, determining the Minimum Sum Insured, the level of any Compulsory Excess, specimen policy documents, clarifying the nature of any options such as the inclusion of Accidental Damage, and the Annual Cost based on the Minimum Sum Insured.

A limitation of this study which is duly acknowledged is one of geography. We restricted the study to Scotland, as with only 32 local authorities we were able to carry out a census of the whole population, rather than a sample of the almost 500 local authorities in the U.K. While Scotland's system of local government has a number of significant differences from the rest of the U.K., in the main it is very similar. Furthermore, both the national government at Westminster and the Scottish Executive in Edinburgh have very similar strategies relating to increasing financial inclusion. Finally, all of the insurers who operate in the Scottish arena are either U.K.-wide or international companies. There is, therefore, no distinctive Scottish element to the cover and pricing structure. While the empirical element of the study is, therefore, restricted to Scotland, we would argue that the results have, at the very least, U.K.wide implications. In addition, the question of financial exclusion of low-income groups is one which has troubled a number of governments in developed economies. Our results, therefore, could be expected to have relevance and interest outside of the Scottish context. 
Table 1 Profile of Scottish local authorities

\begin{tabular}{|c|c|c|c|}
\hline Local authority & No. of LA tenancies & Area (Hectares) & Population per Hectare \\
\hline Aberdeen City & 26,510 & 18,576 & 11.42 \\
\hline Aberdeenshire & 15,125 & 631,259 & 0.36 \\
\hline Angus & 9,556 & 218,178 & 0.50 \\
\hline Argyll and Bute & 6,564 & 690,899 & 0.13 \\
\hline Clackmannanshire & 6,115 & 15,864 & 3.03 \\
\hline Dumfries and Galloway & 12,371 & 642,601 & 0.23 \\
\hline Dundee City & 18,478 & 5,983 & 24.35 \\
\hline East Ayrshire & 16,792 & 126,216 & 0.95 \\
\hline East Dunbartonshire & 5,744 & 17,461 & 6.20 \\
\hline East Lothian & 9,553 & 67,918 & 1.33 \\
\hline East Renfrewshire & 3,992 & 17,379 & 5.14 \\
\hline Edinburgh (City of) & 27,455 & 26,373 & 17.01 \\
\hline Eilean Siar & 1,958 & 307,094 & 0.09 \\
\hline Falkirk & 20,285 & 29,737 & 4.88 \\
\hline Fife & 38,188 & 132,486 & 2.64 \\
\hline Glasgow City & 84,790 & 17,549 & 32.93 \\
\hline Highland & 16,945 & $2,565,934$ & 0.08 \\
\hline Inverclyde & 10,301 & 16,046 & 5.25 \\
\hline Midlothian & 7,378 & 35,369 & 2.29 \\
\hline Moray & 6,976 & 223,756 & 0.39 \\
\hline North Ayrshire & 16,474 & 88,539 & 1.53 \\
\hline North Lanarkshire & 45,700 & 46,981 & 6.83 \\
\hline Orkney & 898 & 98,990 & 0.19 \\
\hline Perth and Kinross & 9,484 & 528,581 & 0.26 \\
\hline Renfrewshire & 19,855 & 26,109 & 6.62 \\
\hline Scottish Borders & 6,943 & 473,176 & 0.23 \\
\hline Shetland & 2,170 & 146,648 & 0.15 \\
\hline South Ayrshire & 10,153 & 122,199 & 0.92 \\
\hline South Lanarkshire & 33,441 & 177,193 & 1.71 \\
\hline Stirling & 7,599 & 218,735 & 0.39 \\
\hline West Dunbartonshire & 13,869 & 15,890 & 5.88 \\
\hline West Lothian & 15,792 & 42,733 & 3.71 \\
\hline Total for Scotland & 527,454 & $7,792,452$ & 0.65 \\
\hline
\end{tabular}

Source (population per hectare/area hectares) adapted from 'Social Focus on Urban and Rural Scotland, 2003', Scottish Executive.

\section{Findings on current (2004) provision of "insurance with rent" schemes and "take-up" rate}

The results that follow are a combination of our own research and the data gleaned from the Highland Council survey. These combined results enabled us to formulate answers to the research questions by providing the following information: schemes in existence, take-up rate, policy cover, excess, minimum sums insured, exclusions and cost. This is set out in Table 2 below and is enlarged upon in the sub-sections that follow. 
The Geneva Papers on Risk and Insurance - Issues and Practice

236

Table 2 Insurance with rent schemes available in Scotland

\begin{tabular}{|c|c|c|c|c|c|c|c|c|}
\hline Local authority & $\begin{array}{l}\text { Min } S I \\
(£)\end{array}$ & Excess & Cover & $A D$ & $\begin{array}{l}\text { Annual } \\
\text { cost }(£) \\
\text { based on } \\
\text { min SI }\end{array}$ & $\begin{array}{c}\text { Take } \\
\text { up rate } \\
(\%)\end{array}$ & Provider & r Comments/other features \\
\hline Aberdeenshire & 9,000 & None & $\mathrm{B}$ & Yes & 36.97 & * & RSA & \\
\hline Aberdeen City & $*$ & $*$ & $*$ & $*$ & $*$ & * & $*$ & $\begin{array}{l}\text { No response to Highland } \\
\text { Council Survey } \\
\text { Questionnaire }\end{array}$ \\
\hline Angus & No policy & * & $*$ & $*$ & $*$ & * & $*$ & \\
\hline Argyll and Bute & 9,000 & None & $\mathrm{B}$ & Yes & 41.28 & 20 & NU & \\
\hline Clackmannanshire & 9,000 & None & $\mathrm{B}$ & Yes & 40.62 & $*$ & $\mathrm{AC}$ & \\
\hline City of Edinburgh & 10,000 & None & $\mathrm{C}$ & Yes & 49.92 & 13.5 & RSA & $\begin{array}{l}\text { The cost of the policy } \\
\text { varies dependant upon the } \\
\text { level of AD cover required }\end{array}$ \\
\hline $\begin{array}{l}\text { Dumfries and } \\
\text { Galloway }\end{array}$ & No policy & $*$ & $*$ & $*$ & $*$ & $*$ & $*$ & \\
\hline Dundee City & $*$ & $*$ & $\mathrm{~B}$ & Yes & $*$ & 20 & M/RSA & \\
\hline East Ayrshire & 11,000 & None & B & Yes & 68.64 & 11.3 & RSA & \\
\hline East Dunbartonshire & 10,000 & None & $\mathrm{B}$ & Yes & 70.56 & 23 & NU & \\
\hline East Lothian & 10,000 & None & A & Yes & 38.88 & 9.5 & NU & \\
\hline East Renfrewshire & 9,000 & None & $\mathrm{B}$ & Yes & 66.72 & $*$ & M/RSA & \\
\hline Eilean Siar & No policy & $*$ & $*$ & $*$ & $*$ & * & $*$ & \\
\hline Falkirk & 9,000 & None & $\mathrm{C}$ & Yes & 38.88 & 11 & M/RSA & $\begin{array}{l}\text { Additional AD cover is } \\
\text { provided }\end{array}$ \\
\hline Fife & 10,000 & None & $\mathrm{B}$ & Yes & 50.40 & 8 & $\mathrm{M} / \mathrm{RSA}$ & \\
\hline Glasgow City & 8,000 & None & $\mathrm{B}$ & Yes & 42.48 & * & M/RSA & \\
\hline Highland & 9,000 & None & $\mathrm{C}$ & Yes & 25.92 & $*$ & RSA & Legal cover provided \\
\hline Inverclyde & 9,000 & None & $\mathrm{B}$ & Yes & $*$ & $*$ & NU & \\
\hline Midlothian & No policy & $*$ & $*$ & $*$ & $*$ & $*$ & $*$ & \\
\hline Moray & 9,000 & None & A & Yes & $*$ & 10.5 & NU & \\
\hline North Ayrshire & 9,000 & None & $\mathrm{B}$ & Yes & 38.40 & $*$ & RSA & \\
\hline North Lanarkshire & $*$ & Yes & $\mathrm{C}$ & Yes & $*$ & 22 & $\mathrm{G}$ & $\begin{array}{l}\text { Excess applies to AD } \\
\text { Claims./extra premium for } \\
\text { AD cover }\end{array}$ \\
\hline Orkney & $*$ & $*$ & $*$ & $*$ & $*$ & * & $*$ & $\begin{array}{l}\text { No response to Highland } \\
\text { Council Survey } \\
\text { Questionnaire }\end{array}$ \\
\hline Perth and Kinross & 10,000 & None & $\mathrm{B}$ & Yes & 49.92 & 5 & RSA & \\
\hline Renfrewshire & 9,000 & None & $\mathrm{B}$ & Yes & 48.00 & 4 & RSA & \\
\hline Scottish Borders & 10,000 & None & $\mathrm{C}$ & Yes & 34.08 & 17 & RSA & Legal cover applies \\
\hline Shetland & No policy & $*$ & $*$ & $*$ & $*$ & $*$ & $*$ & \\
\hline South Ayrshire & No policy & $*$ & $*$ & $*$ & $*$ & * & $*$ & \\
\hline South Lanarkshire & 8,000 & None & $\mathrm{C}$ & Yes & 47.52 & $*$ & M/RSA & Legal helpline \\
\hline Stirling & 9,000 & Yes & $\mathrm{C}$ & Yes & 40.80 & $*$ & G & $\begin{array}{l}£ 50 \text { excess applies to AD } \\
\text { claims/additional premium } \\
\text { for extra AD cover }\end{array}$ \\
\hline $\begin{array}{l}\text { West } \\
\text { Dunbartonshire }\end{array}$ & 9,000 & None & $\mathrm{B}$ & Yes & 45.60 & 11 & PG & \\
\hline West Lothian & 10,000 & Yes & $\mathrm{B}$ & Yes & 45.60 & 19 & RSA & $\begin{array}{l}\text { Excess dependant upon } \\
\text { type of claim }\end{array}$ \\
\hline
\end{tabular}

RSA, Royal SunAlliance; G, Groupama; PG, Primary Group; NU, Norwich Union; M/RSA, Marsh \& Royal SunAlliance; AC, Allianz \& Cornhill.

*Information unavailable or not provided.

Cover: A, basic; B, intermediate; C, advanced. 


\section{Schemes in existence}

In terms of availability of schemes, at least 24 (75 per cent) of local authorities in Scotland are identified as offering insurance with rent contents insurance policies to their tenants. Three insurance organizations dominate as scheme providers - Royal \& SunAlliance, Norwich Union and Marsh (the latter being an insurance broker managing a scheme on behalf of underwriters).

\section{The "take-up" rate}

Where known, the "take-up" rate (the percentage of tenants taking out the "insurance with rent" schemes compared to the total of tenancies controlled) for each Scottish local authority is shown in Table 2. The takeup of the insurance with rent scheme among local authority tenants is, however, very low, ranging from 4 to 23 per cent in authorities responding to the survey. The average is only 13.7 per cent. We cannot, of course, say with certainty that those not in the scheme are uninsured. Some tenants will undoubtedly have arranged their own cover outwith the scheme - possibly arranged before the scheme came into being.

\section{Policy cover}

The information on policy cover has been compiled from the data acquired by our direct contact with the local authorities and provided by them. Our aim in examining policy cover is to establish how the cover offered under schemes compares to policies generally available to the insuring public. It would be relevant to the issue of scheme uptake if cover was in any way inferior to the market average. Our enquiries revealed that the cover provided by insurers varies among local authority areas. To provide some means of comparison we have used the following broad policy types in the Table: A (Basic), B (Intermediate) and C (Advanced) that tend to cover the following:

Type $A$ - Covers fire, theft, vandalism, water damage.

Type $B$ - Policy covers: theft or attempted theft, fire, explosion lightning, earthquake, water or oil escaping from any fixed water or heating installation or domestic appliance; the building being hit by an aircraft, flying object or anything falling from it, or by a vehicle, train or animal; falling trees or branches; riot, civil commotion, strikes, labour or political disturbances; malicious persons or vandals; storm or flood; cost of rent or other accommodation if the insured home cannot be lived in due to specified causes; temporary removal of home contents; deep freezer contents; tenant's liability and third party liability; accidental death; stolen keys; tenant's improvements; replacement of documents.

Type C-Generally, type C cover tends to be the same as type B but with slight additional elements of cover. For example, type $\mathrm{C}$ offer more cover such as legal cover, $24 \mathrm{~h}$ legal helplines and optional accidental cover at an extra premium.

We found differences and similarities when we compared the cover provided by each scheme policy. For example, so-called "accidental damage" (AD) to items in the home differs between policies but all policies have basic cover for mirrors, fixed glass 
furniture, TV and video players/recorders. For an additional premium, policyholders in the City of Edinburgh Council, Stirling Council and North Lanarkshire Council may include a wider form of $\mathrm{AD}$ cover. To summarize the position on policy cover, all scheme policies have basic cover for theft, fire, flood and water damage to contents and most policies provide cover for vandalism, explosion, lightning, earthquake, smoke, riots, civil commotion, political disturbances, water or oil escaping from fixed heating or domestic appliances and falling aerials. The generally high level of cover provided by the schemes is a surprising discovery as it could be expected that the cover offered would be very basic in order to facilitate the lowest possible premium costing for the scheme at the same time as catering for the most common catastrophe risks that might be faced by tenants. In terms of policy cover, the policies offer a comprehensive cover that is very comparable to any other home policy, that is, the scheme policies are not conspicuously inferior or, in any sense, basic in cover. The documents are uncomplicated (certainly no more so than for any "high street" or web sold policy).

\section{Excess}

A standard claim excess is imposed by only three of the scheme policies examined, with the excess applicable dependant upon the nature of claim made. Although the lack of an excess could encourage policyholders to claim, it also ensures that if a claim is made, the policyholder does not have to find additional money to pay the excess. This feature could, possibly, make the scheme more desirable to local authority tenants.

\section{Minimum sums insured}

The minimum sum insured on each policy differs from Council to Council and according to whether or not the tenant is over 60 years old. In East Ayrshire Council, the minimum sum insured is $£ 11,000$ (age under 60 years) and $£ 9,000$ (age 60 years or over). In Glasgow City, it is $£ 8,000$ (age under 60 years) and $£ 5,000$ (age 60 years and over). The benefit of providing different sums insured to those over 60 years is that the premium will be lower and, therefore, possibly more affordable for those receiving state pension. Pensioners over 60 years who are living on their own or no longer have family residing with them may have fewer possessions to insure than, say, a family with children. It is, therefore, sensible to offer lower sums insured which may increase participation among those over 60 years and is certainly a relevant factor in terms of the overall attraction of a scheme.

\section{Exclusions}

Examination of scheme details revealed a range of exclusions that, in the normal way of insurance policy wordings, play a part in shaping the cover provided. Tenants apply for cover by completing an application form that is no more complicated (and often less so) than any other home contents insurance proposal form. In terms of 
underwriting consideration of this proposal information, in most cases, tenants can be excluded if they are in rent arrears, convicted criminals or multiple claimants. In addition, those who have previously been flooded or have previously been refused insurance may be excluded depending upon the terms of the policy. It is clear that although covers have, typically, been adapted to be attractive to scheme clients and rely upon considerable delegated authority to Council administrators, they do allow underwriters to maintain considerable control as to who is eligible to enter the insurance pool.

Cost

We find that, in general, scheme policies represent excellent value (although one Council Risk Manager did advise us that it was possible to obtain a lower than scheme premium by going to a scheme insurer direct). As a more typical example, our enquiries revealed that as a result of a higher minimum sum insured and a higher level of standard cover, it is much more expensive to insure home contents in a Glasgow City centre property through a "high street", a tele-sales or a web-based insurance provider than with the Glasgow City Council scheme. Specifically, to insure a property via the internet it would cost $£ 284.12$ per annum for a policy underwritten by Royal \& Sunalliance and $£ 561.00$ through Norwich Union (source internet: www.morethan.com, www.norwich-union.co.uk, 22 September 2004). By comparison, it would cost $£ 42.48$ per annum (albeit for a lower minimum sum insured and a lower level of standard cover) through the scheme provided by Glasgow City Council and underwritten by Royal Sunalliance. As with all delegated authority insurance schemes, savings are made by insurers when Councils handle the bulk of the client contact possibly with the exception of claims handling. This is, however, offset by granting the Council a commission or levy of between 15 and 20 per cent of gross premiums in order to cover administration costs.

\section{Conclusion}

Our study indicates good availability of home contents insurance for local authority tenants in Scotland through special insurance with rent schemes. Although in the hands of a small number of underwriters choosing to specialize in this area, there is no doubt that insurers are interested in this source of business. Scope of cover and cost compare favourably to policies generally available to the public. Conditions and underwriting policy are no more restrictive than non-scheme policies. The insurance industry is providing a product which has the potential to offer easy access to home contents insurance and thus to counter one aspect of financial exclusion.

Many of the theoretical reasons for low take up of traditional high street policies are addressed by insurance with rent schemes. Yet despite good product availability, the take-up rate by tenants is low, ranging from 4 to 23 per cent across Scottish local authorities. It is evident from our research that whether through ignorance of the existing low-cost yet generally comprehensive schemes, through apathy, from lack of funds or for some other reason, the majority of tenants are not availing themselves of 
the products. We can only conclude that unless the public sector landlords make greater effort to market these products and are actively supported in this endeavour by central government, take-up rates are likely to remain low.

\section{Reflection on further research}

We acknowledge that beyond answering our stated research questions in providing a picture of the availability of "insurance with rent" schemes in Scottish public sector housing and the take-up rates by tenants, we leave other questions unanswered, most of them revolving around the issue of why the take-up rate for insurance with rent schemes is low.

\section{How many non-scheme tenants have home contents cover?}

The literature on financial exclusion appears to be fairly consistent on the topic of household contents insurance. ${ }^{40}$ It is claimed that around 20 per cent of U.K. households do not have this very important form of cover, although closer analysis would suggest that the figure in lower socio-economic groups is closer to 50 per cent. Our study would suggest that, in Scotland, the level of uninsured public sector housing tenants may be higher than this. As we noted earlier, we cannot say with certainty that those not in the scheme are uninsured but we judge that it is unlikely that a large proportion of tenants who are not availing themselves of scheme cover are, in fact, purchasing their household contents insurance through other routes. It would be helpful to shed light on this by research that questions non-purchasing tenants.

\section{Method of payment of social security benefits}

Those local authorities who operate schemes allow instalments of premium to be paid as part of the rent for the house. In itself this appears to readily facilitate access to the insurance. It must be borne in mind, however, that a considerable number of public sector housing tenants do not actually pay rent. Being entitled to certain social security benefits, their rent will be paid by the state. The state will not, however, pay additional elements such as insurance, leaving the tenant to make their own arrangements. Many tenants therefore have to proactively pay an insurance premium rather than merely have it absorbed into a payment for rent. Automatic payment through a bank account may be an unlikely possibility, given that the $\mathrm{OFT}^{41}$ concluded that lack of access to direct debit facilities is a contributory factor to non-participation. It can, therefore, be seen that not having to physically pay the rent may exclude a large number of tenants from the schemes. It would also be helpful to shed light on this by research that questions non-purchasing tenants.

\footnotetext{
${ }^{40}$ For example OFT (1999).

${ }^{41}$ Ibid.
} 


\section{Policy conditions}

Given the a priori concerns over insurers' attitude to perceived high-risk areas, it is noticeable from our study that there are few restrictive conditions beyond what would be normal underwriting practice. Although minimum sums insured are common, neither these, nor indeed policy excesses, are set at particularly high levels. These aspects of the underwriting of the policies therefore address the OFT's ${ }^{42}$ concern relating to "high street" policies. A relatively common condition, however, is one relating to tenants in rent arrears being either denied access to, or being removed from, the schemes. As stated earlier, many public sector tenants have their rent paid by the state. An appreciable number of those who either pay all, or part, of their rent will undoubtedly fall into the commonly termed "poverty trap", that is, they earn income above the housing benefit threshold, but are still firmly in the low-pay category. This existence on the financial margins means that rent default is always a possibility, and with it exclusion from the insurance with rent schemes. It would also be helpful to shed light on this by research that questions scheme operators and tenants.

\section{Understanding and awareness of schemes}

Given the generally accepted low level of financial awareness in low-income areas, we have concerns about the marketing of schemes. On the one hand, it is clear that governments accept that financial inclusion is to be encouraged, with the Scottish Executive $^{43}$ specifically advocating insurance with rent schemes. Having set the policy context for this, the evidence would point to the scheme insurers addressing many of the concerns regarding "traditional" household contents policies and offering a product tailored for the social housing market. Beyond that, however, there is little evidence from our study to indicate any high profile marketing of the schemes. It would also be helpful to shed light on this by research that questions the Scottish Executive, the scheme operators and tenants.

Cost

As regards price, the evidence from our study is that the products are priced competitively, especially when the cost is spread over 12 monthly payments. We found a sizeable range of prices but, interestingly, there is no apparently strong correlation between the cost and the general level of risk associated with the particular local authority area. For example, the premium for Glasgow City Council (£42.48) is not materially different from the rural Argyll and Bute (£41.28), despite Glasgow being an area of much higher risk in relation to theft, vandalism and other crimes. Although it must be accepted that for households on the financial margins any additional burden on the domestic budget may be problematic, there is insufficient evidence to indicate

\footnotetext{
${ }^{42}$ Ibid.

${ }^{43}$ Scottish Executive (2003a).
} 
that cost would be a significant barrier to take-up of the schemes. It would be helpful to shed light on this by research that questions scheme and non-scheme tenants.

We, therefore, propose to undertake more detailed research to establish why these apparently effective schemes are not more popular. This research will feature a greater focus on the tenants themselves and will seek to determine their knowledge of the products, their perception of them, that is, cost, cover, value for money, and where they sit in priorities. This further research should provide useful guidance to local authorities on the design and marketing of schemes and contribute additional insights into important aspects of financial exclusion which have implications beyond Scotland.

\section{Acknowledgements}

The authors gratefully acknowledge the assistance of Colin Mackenzie and The Highland Council, Inverness, Scotland in sharing the results of their survey of Scottish local authority insurance with rent schemes.

\section{References}

Allen, K. and Rainie, L. (2002) Parents Online, Washington, DC: Pew Internet and American Life Project. Association of British Insurers (1995) 'IPT: a good or bad tax?' Insurance Trends (July), pp. 1-5.

Association of London Authorities (1994) At a Premium: The Cost of Home Contents Insurance to Londoners, London: ALA.

British Bankers Association (2000) 'Promoting financial inclusion - The work of the Banking industry', available online atwww.bba.org.uk/public/consumers/1667.

Bronheim, S., Magrab, P. and Crowel, R. (2000) Social Exclusion in the United States: Policy Implications for Community Solutions, Paris: Organisation for Economic Co-operation and Development.

Canadian Co-operative Association (2002) Micro-insurance for Macro Benefits, available online atwww.coopcca.com/pdf/newsletter/IDDigest/Autumn2002/8-AUT02.pdf.

Carvin, A. (2000) 'Mind the gap: the digital divide as the civil rights issue of the new millennium', MultiMedia Schools (January/February), available online atwww.infotoday.com $/ \mathrm{mmscholls/jan00/}$ carvin.htm.

Combes, J. (1998) Preliminary Approach to the Concept of Social Exclusion, Paris: Organisation for Economic Co-operation and Development.

CRSIS (2003) Regional Financial Inclusion Strategies, Centre for Research into Socially Inclusive Services Edinburgh: Heriot Watt University.

Dancer, H. (2002) 'Scottish rent to include flood cover', Insurance Times (8th August).

Davison, E. and Cotten, S.R. (2003) 'Connection discrepancies: unmasking further layers of the digital divide', First Monday 8(3). Available online atwww.firstmonday.org/issues/issue8_3/Davison.html.

DFID (2004) Adaptation to Climate Change: Can Insurance Reduce the Vulnerability of the Poor?, London: Department for International Development.

Financial Services Authority (2000) In or Out? Financial Exclusion: A Literature and Research Review, London: Financial Services Authority.

Gill, M. and Turbin, V. (1997) 'Insurance in the inner-city: Is red-lining fact or fiction?' The Journal of the Society of Fellows, The Chartered Insurance Institute 11: 29-37.

Hargittai, E. (2002) 'Second-level digital divide: Differences in people's online skills', First Monday 7(4). Available online atwww.firstmonday.org/issues/issue7_4/hargittai/index.html.

Highland Council (2004) Home Contents Insurance Schemes - Survey, The Highland Council, Glenurquhart Road, Inverness, Scotland IV3 5NX. 
HM Treasury (1999) PAT 14 Access to Financial Services: National Strategy for Neighbourhood Renewal, available online athttp://www.renewal.net/Documents/RNET/Policy\%20Guidance/Accessfinancialservices.pdf.

Kempson, E. and Whyley, C. (1999) Kept Out or Opted Out? Understanding and Combating Financial Exclusion, Bristol: The Policy Press/Joseph Rowntree Foundation.

Lewis, H. (1989) Insuring against burglary loss, Research and Planning Unit Paper 52, The Home Office, London.

Mansell, R. (2002) 'From digital divides to digital entitlements in knowledge Societies', Current Sociology 50: $407-426$

National Consumer Council (1994) Consumer Concerns 1994: A Consumer Review of Personal Financial Services, London: National Consumer Council.

National Statistics (2003) Family spending: A report on the 2002-2003 expenditure and food survey, TSO, HMSO, London.

Office of the Deputy Prime Minister (2004) Tackling social exclusion: Taking stock and looking to the future. Emerging findings, Social Exclusion Unit, Office of the Deputy Prime Minister, London.

OFT (1999) Vulnerable consumers and financial services: A report of the Director General's Enquiry, Office of Fair Trading, London.

Palmer, G., North, J., Carr, J. and Kenway, P. (2003) Monitoring poverty and social exclusion: 2003, New Policy Institute, Joseph Rowantree Foundation.

Palmer, G., Carr, J. and Kenway, P. (2004) Monitoring poverty and social exclusion in Scotland: 2004, New Policy Institute, Joseph Rowantree Foundation.

Scottish Consumer Council (1996) Under cover: Home contents insurance schemes for local authority tenants, Scottish Consumer Council, Glasgow.

Scottish Executive (2003a) A partnership for a better Scotland, Scottish Executive, Edinburgh.

Scottish Executive (2003b) Scotland's people: Results from the 2003 Scottish Household Survey, Annual report: TNS Social and MORI Scotland, A Scottish Executive National Statistics Publication.

Shires, I. (2002) 'Insuring the uninsured', Insurance and Financial Services Review (September): 11-12.

Sinclair, S. (2001) Financial Exclusion: an introductory survey, CRSIS: Centre for Research into Socially Inclusive Services, Edinburgh: Heriot Watt University.

USAID (1999) Providing insurance to low-income households; Part 1: A primer on insurance principles and products, Microenterprise Best Practices, Bethesda MD.

USAID (2000) Insurance in low-income communities; Part 2: Initial lessons from micro-insurance experiments for the poor, Microenterprise Best Practices, Bethesda MD.

Whyley, C., McCormick, J. and Kempson, E. (1998a) 'Why are some people without home contents insurance?' Insurance Trends 16: 7-12.

Whyley, C., McCormick, J. and Kempson, E. (1998b) Paying for Peace of Mind: Access to Home Contents Insurance for Low-income Households, London: Policy Studies Institute.

\section{About the Authors}

Dr John Hood is a Lecturer in Risk Management at Glasgow Caledonian University. He has a number of research and teaching interests, including insurance, public sector risk management and the management of risks facing multi-national businesses. $\mathrm{He}$ has published widely on all these topics.

Dr William Stein is a Senior Lecturer in Risk Management at Glasgow Caledonian University. He teaches and researches in risk management and insurance. He has a particular interest in local authority and health service risks.

Claire McCann is a Research Assistant in the Centre for Risk \& Governance at Glasgow Caledonian University. 